\title{
The use of simple skin excision and periosteal suture in the treatment of pachydermoperiostosis frontal skin thickening
}

\section{Sevgi Kurt Yazar, ๑ Merdan Serin, ๑ Selami Serhat Șirvan*, ๑ Memet Yazar*, ๑ Fatih Irmak*}

İstanbul Training and Research Hospital, Clinic of Plastic Surgery, İstanbul, Turkey

*Șisli Etfal Training and Research Hospital, Clinic of Plastic Surgery, İstanbul, Turkey

\begin{abstract}
Pachydermoperiostosis (PDP) is a primary hypertrophic osteoarthropathy which can result in a coarse facial appearance. In this study we present treatment results of a case in which a simple skin excision and periosteal anchoring was used to treat frontal skin thickening in a patient with PDP.

Keywords: Pachydermoperiostosis, face, pachydermia

Öz

Pakidermoperiostozis (PDP) kaba yüz görünümüne sebep olabilen bir primer hipertrofik osteoartropatidir. Bu çalısmada, frontal bölgedeki kaba deri katlantılarının görünümü nedeniyle tarafımıza başvuran PDP'li bir hastaya basit deri eksizyonu ve periostal sütürler ile yapılan tedavinin sonuçları sunulmaktadır.

Anahtar Kelimeler: Pakidermoperiostozis, yüz, pakiderma
\end{abstract}

\section{Introduction}

Pachydermoperiostosis (PDP) is a rare hereditary disease. It was first described in 1868. It is the primary form of hypertrophic osteoarthropathy. Men are more often affected than females (7:1). PDP can result in symptoms such as finger clubbing, periostosis, pachydermia (thickening of the skin) and coarse facial appearance. It is also known as TouraineSolente-Gole syndrome ${ }^{1}$. It usually starts during the second decade of life and has been known to mimic acromegaly ${ }^{2}$. There are reports of frontal rhytidectomy, direct excision of nasolabial fold, botulinum toxin A and eyelid procedures for the treatment of the facial appearance complaints in patients with $\mathrm{PDP}^{3-5}$. In this paper we present a case with PDP which was treated with skin excision followed by periosteal anchoring of the forehead skin.

\section{Case Report}

Twenty-year-old male patient was presented to our clinic with the complaint of the facial appearance. Physical examination revealed typical face appearance with hypertrophy on the forehead skin and prominent nasolabial groove. The patient also had hypopigmented macular skin lesions on the bilateral upper extremity, chest wall and the back as well and asymmetric bone growth on the extremities. Excision of the thickened parts of the skin was performed on the bilateral forehead to treat the forehead appearance. Defects

Address for Correspondence/Yazıșma Adresi: Merdan Serin MD, İstanbul Training and Research Hospital, Clinic of Plastic Surgery, İstanbul, Turkey Phone: +90 5055581385 E-mail: merdanserin@gmail.com Received/Geliş Tarihi: 15.01.2019 Accepted/Kabul Tarihi: 21.04.2020 ORCID: orcid.org/0000-0003-3416-8605

(c) Copyright 2020 by Turkish Society of Dermatology and Venereology

Turkderm - Turkish Archives of Dermatology and Venereology published by Galenos Yayinevi. 
were closed primarily. During the closure of the defects the skin was anchored to the periosteum with 4.0 PDS horizontal mattress sutures to prevent skin laxity and recurrence (Figure 1,2). After the procedure skin biopsies were performed from the skin lesions on the chest wall and the extremities.

Histopathological examination of the excised tissues and biopsies revealed thickened and eosinophilic appearance on the collagen fibers. In addition to these findings the excised tissues from the forehead skin revealed collagen hyalinization and rare perivascular lymphocytes. Periodic Acid Schiff + Alcian Blue staining shows minimal amount of mucin production between the collagen fibers.

The patient was doing well 6 months after the surgery with high rate of aesthetic satisfaction with no sign of recurrence of the skin thickening. Informed consent was obtained.

\section{Discussion}

Forehead and nasolabial regions are the most common areas affected in the facial region of PDP patients. Rhytidectomy is one of the most common procedures to address these changes. But since the epidermis is hyperkeratotic and the dermis is thicker in these patients, stretching

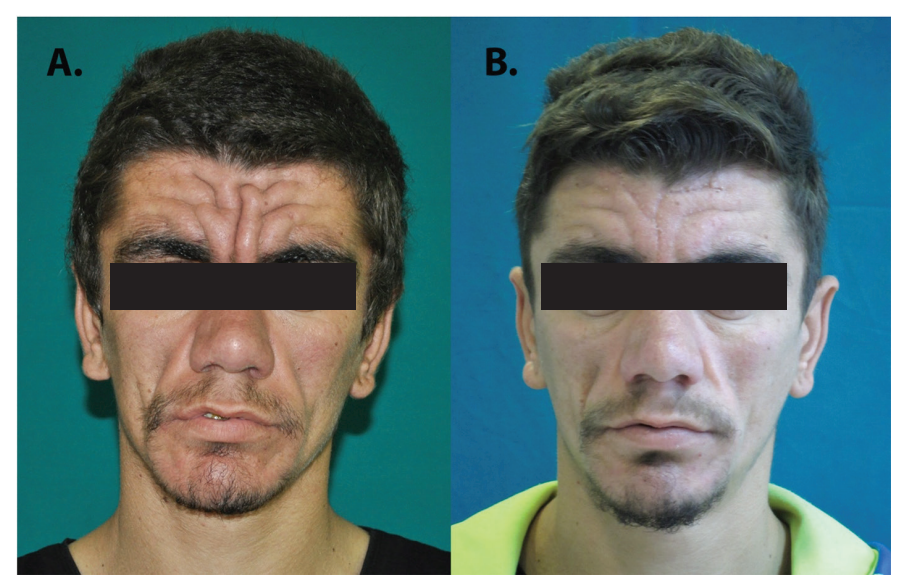

Figure 1. a) Preoperative and $\mathbf{b}$ ) postoperative view of the patient

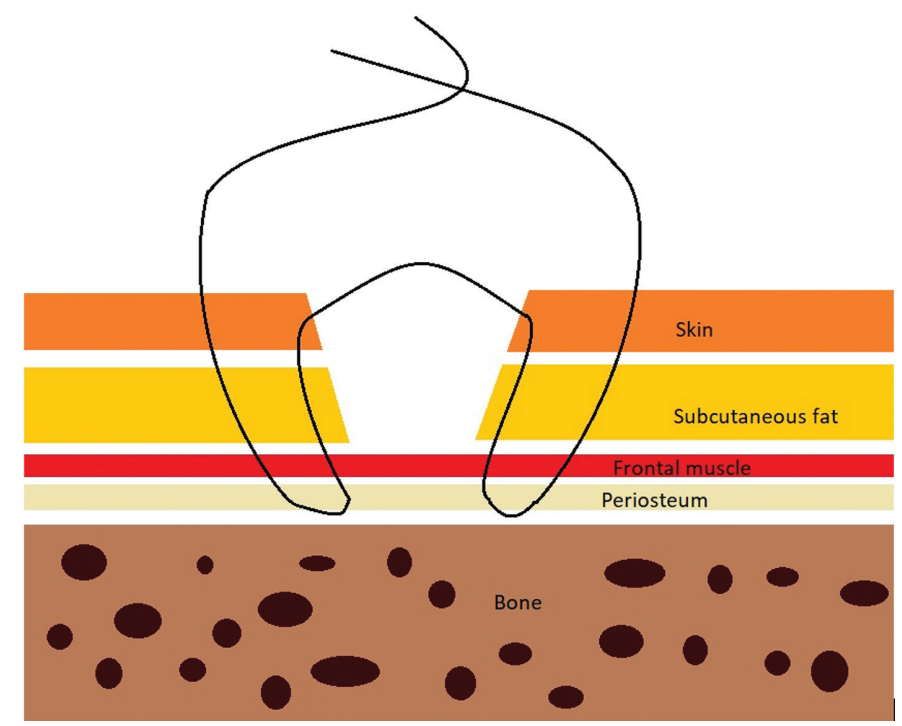

Figure 2. Illustration of the periosteal anchoring suture of the skin with conventional rhytidectomy approach might not be sufficient especially in the forehead and scalp area. In addition, rhytidectomy is associated with more severe complications when compared with simple skin excision ${ }^{6}$. Skin expansion has been reported as an alternative treatment in PDP patients ${ }^{7}$. This approach can be combined with the simple skin excision to provide smooth skin for the closure of the defect.

Subperiostal skin rhytidectomy have been advocated by some surgeons as more effective than conventional rhytidectomy in the treatment of PDP. The thickened periosteum can be addressed with this approach which causes the deep wrinkles in these patients. But despite the advantages this approach too has potential for serious complications such as bleeding and necrosis ${ }^{8}$.

Botulinum toxin $A$ has been offered as an alternative to surgical treatments in patients with less severe skin grooves ${ }^{9}$. But this treatment has limited effectiveness in patients with deep and severe grooves. Simple excision with periosteal anchoring can be alternative in these patients who do not prefer frontal rhytidectomy. Although frontal rhytidectomy could potentially end in better aesthetic results with less apparent scaring prolonged operation time and the need for general anesthesia could be undesired for some patients ${ }^{10}$.

We believe that this simple excision technique can be very effective in treatment of frontal facial grooves associated with PDP in cases where more invasive procedures are not considered. This procedure can achieve a very high patient satisfaction with a relatively low risk of complication.

\section{Ethics}

Informed Consent: It was obtained.

Peer-review: Externally peer-reviewed.

\section{Authorship Contributions}

Surgical and Medical Practices: S.K.Y., M.S., Concept: S.K.Y., Design: S.K.Y., M.S., Data Collection or Processing: S.K.Y., M.S., S.S.S., M.Y., F.I., Analysis or Interpretation: S.K.Y., M.S., S.S.Ş., M.Y., F.I., Literature Search: S.K.Y., M.S., S.S.Ş., M.Y., F.I., Writing: S.K.Y., M.S.

Conflict of Interest: No conflict of interest was declared by the authors.

Financial Disclosure: The authors declared that this study has received no financial support.

\section{References}

1. Pramatarov K, et al., [Pachydermoperiostosis (Touraine-Solente-Gole syndrome)]. Z Hautkr 1988;63:55-6.

2. Sharma ML, Singh $Y$, Garg MK, Brig, Mishra S: Pachydermoperiostosis mimic to acromegaly. Med J Armed Forces India 2015;71(Suppl 1):S187-S9.

3. Monteiro E, Carvalho P, Silva A, Ferraro A: Frontal rhytidectomy: a new approach to improve deep wrinkles in a case of pachydermoperiostosis. Plast Reconstr Surg 2003;112:1189-91.

4. Ohtsuka M, Takayanagi S: Eyelid reconstruction in pachydermoperiostosis. Plast Reconstr Surg, 1988;81:88-90.

5. Rouveroux C, Binder JP, Revol M, Servant JM: [Direct excision of the deep nasolabial fold: a logical and easy surgical management]. Ann Chir Plast Esthet 2006;51:211-6.

6. Taichao D, Fuling L, Hengguang Z: Comprehensive surgical strategies for the management of pachydermoperiostosis. Facial Plast Surg 2018;34:330-4.

7. Liu CY, Zhang YF: Images in clinical medicine. Pachydermoperiostosis. N Engl J Med 2014;370:1930. 
8. de Sousa Fiorini Lima J, da Costa SM, Júnior AC, Bezerra MM, Polizzi LQR, Polizzi RJ: Surgical treatment of primary pachydermoperiostosis: Report of two cases. Brazillian Journal of Plastic Surgery 2014;29.

9. Bingol UA, Cinar C: Pachydermoperiostosis: aesthetic treatment of prematurely aging face with facelift and botulinum toxin a. J Craniofac Surg 2014;25:e563-e4.
10. Verjee LN, Greig AV, Kirkpatrick WN: Craniofacial strategies for the management of pachydermoperiostosis-a case report and review of the literature. J Plast Reconstr Aesthet Surg 2009;62:e511-e3. 